\title{
Assessment of Heavy Metals in Some Vegetables Sold in Urban Open Markets of Kathmandu Valley
}

\author{
Pawan Raj Shakya and Neena Malla Khwaounjoo \\ Padma Kanya Multiple Campus, Tribhuvan University, Kathmandu, Nepal \\ e-mail: pawansh2003@yahoo.com
}

\begin{abstract}
Present study describes the extent of heavy metal contamination in two vegetable types viz., cabbage (Brassica oleracea var capitata) and cauliflower (Brassica oleracea var botrytis) sold in urban open markets of Kathmandu valley. A total of 18 vegetable samples collected from various market sites of the valley were analyzed for heavy metals viz., As, $\mathrm{Cd}, \mathrm{Cu}, \mathrm{Hg}, \mathrm{Pb}$ and $\mathrm{Zn}$ using atomic absorption spectrophotometer (AAS). Results revealed that the metal concentrations in both the vegetables tested were found in the order as $\mathrm{Zn}>\mathrm{Cu}>\mathrm{Pb}>\mathrm{Cd}$. The metal levels in cabbage leaves irrespective of the market sites, ranged between $0.91-2.05 \mathrm{mg} / \mathrm{kg}$ for Cd, $14.32-28.31 \mathrm{mg} / \mathrm{kg}$ for Cu , $7.29-14.70 \mathrm{mg} / \mathrm{kg}$ for $\mathrm{Pb}$ and $36.33-108.09 \mathrm{mg} / \mathrm{kg}$ for $\mathrm{Zn}$ respectively. Similarly, the metal levels in cauliflower varied from $0.81-1.50 \mathrm{mg} / \mathrm{kg}$ for $\mathrm{Cd}, 19.29-26.77 \mathrm{mg} / \mathrm{kg}$ for $\mathrm{Cu}, 10.82-21.23 \mathrm{mg} / \mathrm{kg}$ for $\mathrm{Pb}$ and $62.45-73.72 \mathrm{mg} / \mathrm{kg}$ for $\mathrm{Zn}$ respectively. However, As and $\mathrm{Hg}$ were found below the detection limits in both the vegetables tested. It was also found that while the mean concentrations of $\mathrm{Cd}$ and $\mathrm{Pb}$ exceeded the maximum permissible limits for vegetables, $\mathrm{Cu}$ and $\mathrm{Zn}$ were found within the safe limits as recommended by FAO/WHO. From the present study, we conclude that a regular monitoring of heavy metals in vegetables is necessary for safe consumption as well as to prevent excessive buildup of these metals in the human food chain.
\end{abstract}

Key words: heavy metals, vegetables

\section{Introduction}

Heavy metals are non-biodegradable and persistent environmental contaminants and thus readily accumulate to toxic levels. Implication associated with heavy metal contamination is of great concern, particularly in agricultural production. Dietary exposure to heavy metals like cadmium, lead, zinc and copper in elevated concentrations has been identified as a risk to human health through vegetable consumption (Kachenko \& Singh 2006). Furthermore, consumption of heavy metals-contaminated food can seriously deplete some essential nutrients in the body causing a decrease in immunological defenses, intrauterine growth retardation, impaired psychosocial behavior, disabilities associated with malnutrition and a high prevalence of upper gastrointestinal cancer (Arora et al. 2008). Toxicological significance of these metals has been recognized several decades ago in developed countries (Tsuda et al. 1995).
Main sources of heavy metals to vegetable crops are their growth media (soil, air, nutrient solutions) from which these are taken up by roots or foliage. Soil gets polluted due to waste water irrigation and absorbed minerals settle in edible tissues of the vegetables (Lokeshwari \& Chandrappa 2006). Food safety issues and potential health risks make this as one of the serious environmental concerns (Cui et al. 2005). Though, metals are indispensable part of our environment and play positive role in various biological processes such as signaling, homeostasis and enzyme catalysis, higher concentration of metals tend to toxic effects since they are prone to bioaccumulation and bio-magnification along the food chain. Industrialization and urbanization as well as anthropogenic activities are main source for heavy metal contamination (Begum \& Harikrishna 2010).

The monitoring and assessment of heavy metal concentrations in the vegetables from the market sites 
have, therefore been carried out in some developed (Jorhem \& Sundstroem 1993, Milacic \& Kralj 2003), and developing countries (Jassir et al. 2005, Radwan $\&$ Salama 2006). However, there are very limited literatures available on heavy metal concentrations in vegetables from market sites of Kathmandu valley. Therefore, the aim of the present study was to quantify arsenic (As), cadmium $(\mathrm{Cd})$, copper $(\mathrm{Cu})$, mercury $(\mathrm{Hg})$, lead $(\mathrm{Pb})$ and zinc $(\mathrm{Zn})$ in some mostly consumed vegetable types such as cabbage and cauliflower sold in urban open markets of Kathmandu valley and to evaluate if the vegetables tested were safe for consumption.

\section{Methodology}

\section{Collection of vegetable samples}

Two common vegetable types viz.,cabbage (Brassica oleracea var capitata) and cauliflower
(Brassica oleracea var botrytis) sold in urban open market sites of Kathmandu valley were selected for the present study. A total of 18 samples were randomly collected from Kathmandu, Lalitpur and Bhaktapur districts (three replicates of each vegetable type from each district) respectively during their growing seasons of 2012. Although the vegetable samples were not collected directly from the farming sites, formal interviews with the vegetable grocers revealed that they were grown locally along the polluted riversides of the Bagmati and Bishnumati. Such origins of the vegetable samples were focused for the present study in order to analyze the levels of metal contamination. The details of the vegetable samples are given in Table 1 .

Table 1. Vegetable samples collected from the market sites of Kathmandu valley

\begin{tabular}{l|l|l|l|l}
\hline S.No. & $\begin{array}{l}\text { Common } \\
\text { name }\end{array}$ & $\begin{array}{l}\text { Vernacular } \\
\text { name }\end{array}$ & Botanical name & Market sites \\
\hline 1 & Cabbage & Bandakobi & Brassica oleracea var capitata & Kathmandu $\left(\mathrm{S}_{\mathrm{KB}}\right)$, Lalitpur $\left(\mathrm{S}_{\mathrm{LB}}\right)$, Bhaktapur $\left(\mathrm{S}_{\mathrm{BB}}\right)$ \\
\hline 2 & Cauliflower & Cauli & Brassica oleracea var botrytis & Kathmandu $\left(\mathrm{S}_{\mathrm{KC}}\right)$, Lalitpur $\left(\mathrm{S}_{\mathrm{LC}}\right)$, Bhaktapur $\left(\mathrm{S}_{\mathrm{BC}}\right)$ \\
\hline
\end{tabular}

\section{Determination of heavy metals}

Each $1.0 \mathrm{~g}$ finely powdered sample of the vegetables was taken into $100 \mathrm{ml}$ beakers separately. Fifteen mililiter of tri-acid mixture (70\% high purity $\mathrm{HNO}_{3}, 65 \%$ $\mathrm{HClO}_{4}$ and $70 \% \mathrm{H}_{2} \mathrm{SO}_{4}$ in 5:1:1 ratio) was added to each of the beakers (Allen et al. 1986). The mixture was then digested at $80{ }^{\circ} \mathrm{C}$ till the solution became transparent. It was then cooled and filtered using Whatman filter paper No. 40 and made up to $50 \mathrm{ml}$ with doubly distilled water. The resulting solution was analyzed for concentrations of $\mathrm{As}, \mathrm{Cd}, \mathrm{Cu}, \mathrm{Hg}, \mathrm{Pb}$ and $\mathrm{Zn}$ using an atomic absorption spectrophotometer (Model 2380, Perkin-Elmer, Norwalk, CT, USA). Standard solutions were frequently run to check the sensitivity of the instrument.
All statistical analyses were done on an IBM-PC computer using the Microsoft EXCEL (version 2003).

\section{Results and Discussion}

The levels of heavy metals in the vegetable samples from the urban open markets of Kathmandu valley are presented in Table (2\&3). While $\mathrm{Cd}, \mathrm{Cu}, \mathrm{Pb}$ and $\mathrm{Zn}$ were found at variable levels in the vegetables tested, $\mathrm{As}$ and $\mathrm{Hg}$ were not detected. The mean concentration of $\mathrm{Zn}$ was highest in the vegetables tested followed by $\mathrm{Cu}, \mathrm{Pb}$ and $\mathrm{Cd}$ respectively. A comparative study of heavy metal contamination in the test vegetables collected from various market sites of the valley is presented in Table $2 \& 3$.

Table 2. Heavy metal concentration in $\mathrm{mg} \mathrm{kg}^{-1} \mathrm{dry}$ weight $(\mathrm{n}=3$; SD) in cabbage leaves

\begin{tabular}{l|c|c|c|c|c|c}
\hline Market Site & As & Cd & Cu & Hg & Pb & Zn \\
\hline $\mathrm{S}_{\mathrm{KB}}$ & ND & $1.65(0.24)$ & $17.72(2.05)$ & ND & $7.29(0.87)$ & $108.09(17.94)$ \\
$\mathrm{S}_{\mathrm{LB}}$ & ND & $0.97(0.07)$ & $28.31(4.56)$ & ND & $14.70(2.66)$ & $78.03(9.45)$ \\
$\mathrm{S}_{\mathrm{BB}}$ & ND & $2.05(0.59)$ & $14.32(2.78)$ & ND & $9.62(1.09)$ & $36.33(6.35)$ \\
Mean & - & $1.56(0.55)$ & $20.12(7.30)$ & - & $10.54(3.79)$ & $74.15(36.04)$ \\
*RMLV & 0.43 & 0.2 & 40.0 & 0.01 & 0.3 & 99.40 \\
\hline
\end{tabular}

$\mathrm{ND}=$ Not detected, Levels were below the detection limit;

* Recommended maximum limits for vegetables (FAO/WHO 2001) 
Table 3. Heavy metal concentration in $\mathrm{mg} \mathrm{kg}^{-1} \mathrm{dry}_{\text {weight }}(\mathrm{n}=3$; SD) in cauliflower

\begin{tabular}{l|c|c|c|c|c|c}
\hline Market Site & As & Cd & Cu & Hg & Pb & Zn \\
\hline $\mathrm{S}_{\mathrm{KC}}$ & ND & $0.81(0.16)$ & $19.29(3.54)$ & ND & $10.82(2.45)$ & $62.45(10.82)$ \\
$\mathrm{S}_{\mathrm{LC}}$ & $\mathrm{ND}$ & $1.50(0.21)$ & $24.69(5.67)$ & ND & $15.05(3.54)$ & $73.72(17.55)$ \\
$\mathrm{S}_{\mathrm{BC}}$ & $\mathrm{ND}$ & $1.35(0.09)$ & $26.77(7.56)$ & ND & $21.23(5.61)$ & $59.76(9.56)$ \\
Mean & - & $1.22(0.36)$ & $23.58(3.86)$ & - & $15.70(5.24)$ & $65.31(7.41)$ \\
* RMLV & 0.43 & 0.2 & 40.0 & 0.01 & 0.3 & 99.40 \\
\hline
\end{tabular}

$\mathrm{ND}=$ Not detected, Levels were below the detection limit.

* Recommended maximum limits for vegetables (FAO/WHO 2001)

\section{Level of cadmium $(\mathrm{Cd})$}

Results revealed that the levels of $\mathrm{Cd}$ in cabbage and cauliflower varied from 0.97 to 2.05 and from 0.81 to $1.50 \mathrm{mg} / \mathrm{kg}$ (Table $2 \& 3$ ). While the maximum level of $\mathrm{Cd}$ in cabbage was detected at Bhaktapur market sites $\left(\mathrm{S}_{\mathrm{BB}}\right)$, the maximum level in cauliflower was found at Lalitpur market sites $\left(\mathrm{S}_{\mathrm{LC}}\right)$. On the other side, the minimum levels of the metal in cabbage and cauliflower were recorded respectively at $\mathrm{S}_{\mathrm{LB}}$ and $\mathrm{S}_{\mathrm{KC}}$. Within the sampling sites, the mean concentration of $\mathrm{Cd}$ was found to be 1.56 and $1.22 \mathrm{mg} / \mathrm{kg}$ respectively for cabbage and cauliflower. Both the values were found to have exceeded the maximum permissible limits (Table $2 \& 3$ ) as recommended by FAO/WHO (2001). Besides, it was also found that the level of $\mathrm{Cd}$ in each of the vegetables tested from the markets of the Kathmandu valley exceeded the recommended permissible limits. Sharma and Chettri (2005) also reported similar findings in vegetables grown in agricultural fields along the main riversides of Kathmandu Valley. The high $\mathrm{Cd}$ concentration in the present study is possibly due to the use of contaminated river water for irrigation. Further, use of fertilizers, sewage and compost can remarkably increase the Cd uptake into plant tissues (Alloway \& Jackson 1991). Farooq et al. (2008) reported that based on plant species, their physical and chemical properties, plants could readily absorb $\mathrm{Cd}$ from soil which upon ingestion would enter into human food chain. Cadmium is the most toxic and non-essential heavy metal for living organisms and hence it bioaccumulates leading to health disorders even at low doses (Nagajyoti et al. 2010).

\section{Level of copper $(\mathrm{Cu})$}

The levels of $\mathrm{Cu}$ in the vegetables tested varied from 14.32 to $28.31 \mathrm{mg} / \mathrm{kg}$ in cabbage and 19.29 to $26.77 \mathrm{mg} /$ $\mathrm{kg}$ in cauliflower at the various market sites of the Kathmandu valley (Table 2\&3). The higher concentration of the metal in cabbage was recorded at $\mathrm{S}_{\mathrm{LB}}$ and the lower at $\mathrm{S}_{\mathrm{BB}}$. While the minimum Cu level in cabbage was recorded at $S_{B B}$, the test sample from the same market sites exhibited maximum concentration of it in cauliflower. It was also found that the minimum concentration of the metal in cauliflower was recorded at $\mathrm{S}_{\mathrm{KC}}$. The mean concentration of $\mathrm{Cu}$ irrespective of the sampling sites was found to be higher in cauliflower $(23.58 \mathrm{mg} / \mathrm{kg})$ than in cabbage $(20.12 \mathrm{mg} / \mathrm{kg})$. Interestingly, both the mean values were found below the recommended maximum permissible levels for the vegetables (FAO/WHO 2001). Demirezen and Ahmet (2006) reported that, $\mathrm{Cu}$ concentration $(22.19-76.50 \mathrm{mg} /$ $\mathrm{kg}$ ) was found higher in leafy vegetables as compared to non-leafy vegetables in Turkey which could to be due to richness of chlorophyll. Sharma et al. (2006) reported that $\mathrm{Cu}$ concentration $(2.25-5.42 \mathrm{mg} / \mathrm{kg})$ in vegetables grown in waste water areas of Varanasi, India were within safe limit. The present study is in agreement with the above findings.

\section{Level of lead $(\mathrm{Pb})$}

Lead level ranged between 7.29 and $14.70 \mathrm{mg} / \mathrm{kg}$ in cabbage and between 10.82 and $21.23 \mathrm{mg} / \mathrm{kg}$ in cauliflower at various market sites of the valley (Table $1 \& 2)$. While the higher concentrations of $\mathrm{Pb}$ in cabbage and cauliflower were recorded respectively at the sites, $\mathrm{S}_{\mathrm{LB}}$ and $\mathrm{S}_{\mathrm{BC}}$, the lower concentration of the metal in the same vegetables tested was recorded respectively at the sites, $S_{\mathrm{KB}}$ and $\mathrm{S}_{\mathrm{KC}}$ from Kathmandu. The mean concentration of $\mathrm{Pb}$ in cauliflower $(15.7 \mathrm{mg} / \mathrm{kg})$ was found to be higher than that of the cabbage $(10.54 \mathrm{mg} /$ $\mathrm{kg}$ ). However, the mean levels of $\mathrm{Pb}$ contamination in both the vegetables tested were exceptionally higher than the maximum permissible limits (Table $2 \& 3$ ) for vegetables as recommended by FAO/WHO (2001). Our results are in agreement with the study conducted by Sharma and Chettri (2005) who reported high $\mathrm{Pb}$ 
accumulation above $20 \mathrm{mg} / \mathrm{kg}$ in spinach and carrot grown along various riversides of Kathmandu Valley. Besides, they also found as high as $46.75 \mathrm{mg} / \mathrm{kg}$ of $\mathrm{Pb}$ in soil of those agriculture fields of the valley irrigated with polluted river water. In the present study, the high $\mathrm{Pb}$ concentration in the cabbage and cauliflower clearly indicates its accumulation through the root uptake from the contaminated agriculture fields as the polluted river water is used for the irrigation purpose. Moreover, $\mathrm{Pb}$ deposition in vegetables is also directly related to the atmospheric fall out, exhaust emissions of leaded gasoline and wear and tear of tires (Djingova \& Kuleff 1993).

\section{Level of zinc (Zn)}

Zinc concentration in cabbage ranged between 36.33 and $108.09 \mathrm{mg} / \mathrm{kg}$ and in cauliflower between 59.76 and $73.72 \mathrm{mg} / \mathrm{kg}$ (Table $2 \& 3$ ). While maximum Zn level in cabbage and cauliflower was found respectively at the sites, $S_{\mathrm{KB}}$ and $\mathrm{S}_{\mathrm{LC}}$, the minimum level in the vegetables tested was recorded both from the Bhaktapur sites $\left(\mathrm{S}_{\mathrm{BB}}\right.$ and $\left.\mathrm{S}_{\mathrm{BC}}\right)$. The mean concentration of $\mathrm{Zn}$ in cabbage $(74.15 \mathrm{mg} / \mathrm{kg})$ was found to be higher than cauliflower $(65.31 \mathrm{mg} / \mathrm{kg})$. Both the values did not, however exceed the maximum permissible levels for the vegetables (Table 2\&3). Not only in the present study, Zn hyperaccumulation in plant tissue was observed in most of the cases exceeding critical plant concentration of $200 \mathrm{mg} / \mathrm{kg}$ (Davis \& Beckett 1978). Sharma and Chetri (2005) also reported $462 \mathrm{mg} / \mathrm{kg}$ for $\mathrm{Zn}$ in spinach collected from Shankhamul area near to the Bagmati river of Kathmandu. The possible reason for hyperaccumulation of $\mathrm{Zn}$ in vegetables is due to easy transportation from the roots into the aerial parts.

From the present study it can be concluded that the levels of metal contaminations in cabbage and cauliflower varied considerably among the study sites. Among the heavy metals, Zn was found in significantly high level in the vegetables tested followed by $\mathrm{Cu}, \mathrm{Pb}$ and $\mathrm{Cd}$. However, $\mathrm{As}$ and $\mathrm{Hg}$ were found below the detection levels in both the vegetables tested. The levels of heavy metals in the vegetables, and the permissible levels required for safe food were also compared. $\mathrm{Cu}$ and $\mathrm{Zn}$ levels in the vegetable samples were found well below the maximum limits while $\mathrm{Pb}$ and $\mathrm{Cd}$ exceeded the maximum permissible limits of FAO/WHO. In heavy metal contaminated areas metal accumulating leafy vegetables should be avoided for commercial farming purpose. Instead, they should be substituted by non-accumulator plant like potato.

\section{Acknowledgements}

The Department of Applied Chemistry, Banaras Hindu University, Varanasi is gratefully acknowledged for the AAS analyses. Besides, we are also thankful to Faculty of Science, Padma Kanya Multiple Campus for providing us laboratory facility.

\section{References}

Allen, S.E., H.M. Grimshaw and A.P. Rowland.1986. Chemical analysis. In: Methods in Plant Ecology (Eds. P.D. Moore \& S.B. P.D., Chapman). Blackwell Scientific Publication, London.

Alloway, B.J. and A.P. Jackson.1991. The behaviour of heavy metals in sewage sludge-amended soils. Sci. Total Environ. 100: 151-176.

Arora, M., B. Kiran, S. Rani, A. Rani, B. Kaur and N. Mittal.2008. Heavy metal accumulation in vegetables irrigated with water from different sources. Food Chemistry 111: 811-815.

Begum, A. and S. Harikrishna. 2010. Chemical and heavy metal Profile of Coconut Palms Irrigated with lake water. International Journal of Chem Tech Research 2: $1514-1520$

Cui, Y. J., Y. G. Zhu, R. Zhai, Y. Huang, Y. Qiu and J. Liang.2005. Exposure to metal mixtures and human health impacts in a contaminated area in Nanning, China. Environ. Int., 31: 784-790.

Davis, R.D. and P.H.T. Beckett.1978. Upper critical levels of toxic elements in plant. 11. critical levels of $\mathrm{Cu}$ in young barley, wheat, rape, lettuce and rye grass and of $\mathrm{Ni}$ and $\mathrm{Zn}$ in young barley and rye grass. New Phyto. 80: $23-32$

Demirezen, D. and A. Ahmet.2006. Heavy metal levels in vegetables in Turkey are within safe limits for $\mathrm{Cu}, \mathrm{Zn}$, $\mathrm{Ni}$ and exceeded for $\mathrm{Cd}$ and $\mathrm{Pb}$. J. Food Qual., 29: 252-265.

Djingova, R. and I. Kuleff. 1993. Monitoring of heavy metal pollution by Taraxacum officinale In: Plants as Biomonitors (Ed. B. Markert) VCH. Weinheim / New York / Basel / Cambridge/ Tokyo. Pp.435-460.

FAO/WHO. 2001. Food additives and contaminants, Joint Codex Alimentarius Commission, FAO/WHO. Food standards Programme, ALINORM 01/12A.

Farooq, Md., A. Farooq and R. Umer. 2008. Appraisal of heavy metal contents in different vegetables grown in the vicinity of an industrial area. Pak. J. Bot. 40: 20092016.

Jassir, M.S., A. Shaker and M.A. Khaliq. 2005. Deposition of heavy metals on green leafy vegetables sold on roadsides of Riyadh city, Saudi Arabia. Bull. Environ. Contam. Toxicol. 75: 1020-1027. 
Pawan Raj Shakya \& Neena Malla Khwaounjoo/Assessment of Heavy Metals......

Jorhem, L. and B. Sundstroem. 1993. Levels of lead, cadmium, zinc, copper, nickel, chromium, manganese and cobalt in foods on the Swedish market. J. Food Comp. Anal. 6: 223-241.

Kachenko, A.G. and B. Singh. 2006. Heavy metals contamination in vegetables grown in urban and metal smelter contaminated sites in Australia. Water, Air and Soil Pollution 169: 101-123.

Lokeshwari, H. and G.T. Chandrappa. 2006. Impact of heavy metal contamination of Bellandur Lake on soil and cultivated vegetation. Current Science 91: 622-627.

Milacic, R. and B. Kralj. 2003. Determination of Zn, Cu, $\mathrm{Cd}, \mathrm{Pb}, \mathrm{Ni}$ and $\mathrm{Cr}$ in some. Slovenian foodstuffs. Eur. Food Res. Technol. 217: 211-214.

Nagajyoti, P.C., K.D. Lee and T.V.M. Sreekanth.2010. Heavy metals, occurrence and toxicity for plants: a review. Environ. Chem. Lett. 8: 199-216.
Radwan, M.A. and A.K. Salama. 2006. Market basket survey for some heavy metals in Egyptian fruits and vegetables. Food Chem. Toxicol. 44: 1273-1278.

Sharma, B. and M.K. Chettri. 2005. Monitoring of heavy metals in vegetables and soil of agricultural fields of Kathmandu Valley. Ecoprint 12: 1-9.

Sharma, R.K., M. Agarawal and F.M. Marshall. 2006. Heavy metal contamination in vegetable grown in waste water irrigated areas of Varanasi, India. Bull. Environ. Contamin. Toxicol. 77: 311-318.

Tsuda, T., T. Inoue, M. Kojima and S. Aoki. 1995. Market Basket and duplicate portion estimation of dietary intakes of Cadmium, Mercury, Arsenic, Copper, Manganese and Zinc by Japanese adult. J. AOAC Int. 78: $1363-1368$. 
Nepal Journal of Science and Technology Vol. 15, No.1 (2014) 39-44 